\title{
Artikel
}

\section{De Digital Markets Act en het spectrum van eindgebruikersbescherming}

\author{
Lisanne Hummel, Laura Frederika Lalikova en Viktorija Morozovaite*
}

\section{Inleiding}

Grote onlineplatforms spelen een belangrijke rol in de innovatie en groei van digitale markten waarbij zij zowel zakelijke (bedrijven) als eindgebruikers (voornamelijk consumenten) veel voordelen hebben gebracht. ${ }^{1}$ Zakelijke gebruikers en eindgebruikers zijn echter ook afhankelijk geworden van de grote onlineplatforms. Deze platforms zijn namelijk vaak ingebed in hun eigen platformecosystemen en spelen een poortwachtersrol, waarbij zij het grootste deel van de online transacties tussen zakelij-

L.M.F. Hummel LLM is promovenda aan de Utrecht University School of Law en maakt deel uit van het ERC-gefinancierde Modern Bignessproject onder leiding van prof. dr. Anna Gerbrandy (Grant Agreement No: 852005). Meer informatie op de website: www.uu.nl/en/research/ modern-bigness. L.F. Lalikova LLM is promovenda aan de Utrecht University School of Law en maakt deel uit van het ERC-gefinancierde Modern Bigness-project onder leiding van prof. dr. Anna Gerbrandy (Grant Agreement No: 852005). Meer informatie op de website: www.uu.nl/en/research/modern-bigness. V. Morozovaite LLM is promovenda aan de Utrecht University School of Law en maakt deel uit van het ERC-gefinancierde Modern Bigness-project onder leiding van prof. dr. Anna Gerbrandy (Grant Agreement No: 852005). Meer informatie op de website: www.uu.nl/en/research/modern-bigness.

1. Zakelijke gebruikers: 'een natuurlijke of rechtspersoon die in commerciele of professionele hoedanigheid gebruikmaakt van kernplatformdiensten ten behoeve van of in het kader van het aanbieden van goederen of diensten aan eindgebruikers'; Eindgebruikers: 'elke natuurlijke of rechtspersoon die gebruikmaakt van kernplatformdiensten anders dan als zakelijke gebruiker' (art. 2 lid 17 resp. lid 16 Wet inzake digitale markten/Digital Markets Act). ke gebruikers en eindgebruikers bemiddelen. ${ }^{2}$ Poortwachters hebben een stevig verankerde en duurzame positie opgebouwd in hun eigen markten, waar hun oneerlijke praktijken en het gebrek aan betwistbaarheid kunnen leiden tot inefficiënte resultaten, zoals hogere prijzen, lagere kwaliteit, alsook minder keuze en innovatie voor de consument. ${ }^{3}$ In het afgelopen decennium is het Europese mededingingsrecht gebruikt om deze bezwaren in een aantal op zichzelf staande beschikkingen aan te pakken. Door het systematische karakter van deze uitdagingen lijkt het Europese mededingingsrecht ontoereikend om de ontstane problemen aan te pakken, hetgeen heeft geleid tot Europese regelgeving, waaronder de voorgestelde Wet inzake digitale markten, ook bekend onder de Engelse naam Digital Markets Act (DMA). ${ }^{4}$

Het voornaamste doel van de DMA is om met geharmoniseerde regels enerzijds in te grijpen in de oneerlijke afhankelijkheidsrelaties tussen poortwachters en hun gebruikers en anderzijds het gebrek aan betwistbaarheid van de digitale markten waarop zij actief zijn te verbeteren. ${ }^{5}$ Door middel van de invoering van ver-

2. Voorstel voor een Verordening van het Europees Parlement en de Raad over betwistbare en eerlijke markten in de digitale sector (wet inzake digitale markten) (Digital Markets Act of DMA), $\operatorname{COM(2020)842,~p.~} 1$ (hierna: DMA); J. van Dijck, T. Poell \& M. de Waal, The platform society: Public values in a connective world, Oxford: Oxford University Press 2018; A. Gerbrandy e.a., 'Power in the digital society: A taxonomy of the composite power of Big Tech companies and a theory of Modern Bigness', ASCOLA 2021 Conference 2021.

3. DMA, p. 1; Mededeling van de Commissie aan het Europees Parlement, de Raad, het Europees economisch en sociaal comité en het Comité van de regio's. De digitale toekomst van Europa vormgeven, COM(2020)67 final.

4. Commission Staff Working Document on contestable and fair markets in the digital sector (Digital Markets Act), SWD(2020)363 final, p. 20 (hierna: Commission Staff Working Document on DMA).

5. DMA, p. 4. 
plichtingen en verboden voor poortwachters, probeert de DMA te garanderen dat 'zowel eindgebruikers als zakelijke gebruikers ten volle de vruchten kunnen plukken van de platformeconomie en de digitale economie in het algemeen, in een betwistbare en eerlijke omgeving'. ${ }^{6}$ Het is deze doelstelling die ons doet afvragen wiens belangen werkelijk voorop staan in de DMA en wie dus uiteindelijk de vruchten zal plukken van de platformeconomie: de zakelijke gebruiker of de eindgebruiker? Verschillende belangenorganisaties hebben de DMA bekritiseerd door aan te geven dat de zakelijke gebruiker beter wordt gepositioneerd dan de eindgebruiker. Een analyse van de verplichtingen en verboden voor de poortwachter suggereert echter dat eindgebruikers wel degelijk direct en indirect worden beschermd maar dat de DMA ook een kans voor eindgebruikersbescherming onbenut laat.

In dit artikel delen wij een aantal observaties om deze conclusie te ondersteunen. Daarbij concentreren wij ons op de bepalingen die de (meeste) verplichtingen en verboden voor poortwachters bevatten (art. 5 en 6 DMA). Uit onze observaties blijkt dat er verschillende niveaus van bescherming worden geboden aan respectievelijk zakelijke gebruikers en eindgebruikers. De bescherming voor de eindgebruiker lijkt te bestaan uit een reeks van opeenvolgende niveaus, oftewel een spectrum van bescherming. Aan het ene uiterste van het spectrum biedt de DMA de eindgebruikers directe bescherming en voordelen, terwijl aan het andere uiterste van het spectrum de DMA de eindgebruiker juist nalaat te beschermen. In het midden van het spectrum vinden wij bepalingen die bedoeld zijn om zakelijke gebruikers te beschermen, maar waarvan de eindgebruikers indirect ook profiteren.

Om deze conclusie te illustreren is het artikel als volgt opgebouwd: eerst gaan wij in op de rol die zakelijke gebruikers en eindgebruikers spelen binnen de DMA en op de afhankelijkheidsrelatie tussen de zakelijke gebruikers en de eindgebruikers enerzijds en de poortwachters anderzijds. Hierna volgt een uiteenzetting van de doelstellingen van de DMA: eerlijkheid en betwistbaarheid. Deze eerste twee onderdelen van dit artikel vormen een ijkpunt aan de hand waarvan de analyse van artikel 5 en 6 DMA zal plaatsvinden. Tot slot vatten wij deze analyse samen waarbij wij terugkomen op het eerder geïntroduceerde spectrum van eindgebruikersbescherming. In dit laatste onderdeel zullen de directe voordelen, de indirecte voordelen voor de eindgebruikers en een gemiste kans op bescherming van de eindgebruiker worden belicht.

\section{De Wet inzake digitale markten (DMA)}

De DMA streeft naar eerlijke en betwistbare digitale markten door in artikel 5 en 6 specifieke verplichtingen en verboden op te leggen aan poortwachters, grote onlineplatforms met stevig verankerde en duurzame posities die een aanzienlijke impact hebben op de interne markt en die kernplatformdiensten leveren waarvan andere zakelijke gebruikers en eindgebruikers afhankelijk zijn. ${ }^{7}$ In dit onderdeel introduceren wij de rol van de zakelijke gebruiker en de eindgebruiker ten opzichte van de poortwachter. Wij gaan daarbij dieper in op de doelstellingen van de DMA en de wijze waarop deze doelstellingen de zakelijke gebruiker en de eindgebruiker beogen te beschermen.

\section{De rol van zakelijke gebruikers versus eindgebruikers}

De verplichtingen en verboden van artikel 5 en 6 DMA vormen de kern van de bescherming die de DMA biedt aan de zakelijke gebruiker en de eindgebruiker. Hoewel wij de inhoud van deze bepalingen en hun mogelijke gevolgen hierna zullen bespreken, rechtvaardigt deze bespreking eerst een nadere beschouwing van de begrippen 'zakelijke gebruiker' en 'eindgebruiker' en hun afhankelijkheidsrelatie met de poortwachter.

Poortwachters opereren in meerzijdige markten, waarbij zij als tussenpersonen bemiddelen tussen ten minste twee verschillende gebruikersgroepen - enerzijds zakelijke gebruikers en anderzijds eindgebruikers - die elkaar netwerkvoordelen verschaffen. ${ }^{8}$ Kenmerkend aan meerzijdige markten zijn schaal- en toepassingsvoordelen, netwerkeffecten, lock-in-effecten ${ }^{9}$ en verticale integratie, die er allemaal toe leiden dat poortwachters nu als bemiddelaar optreden in het grootste gedeelte van de online interacties tussen zakelijke gebruikers en eindgebruikers. ${ }^{10}$ Deze meerzijdigheid geeft de poortwachters aanzienlijke controle over de toegang tot digitale platforms en markten, waardoor zowel zakelijke gebruikers als eindgebruikers van hen afhankelijk zijn. De DMA tracht de problemen die voortvloeien uit deze

7. Art. $3 \mathrm{DMA}$; voor een uitputtende lijst van deze platformkerndiensten, zie art. 2 lid 2 DMA

8. A. Hagiu \& J. Wright, 'Multi-sided platforms', International Journal of Industrial Organisation 2015, p. 162-174; J.C. Rochet \& J. Tirole, 'Platform competition in two-sided markets', Journal of the European Economic Association 2003, afl. 4, p. 990-1029.

9. Lock-in-effecten geven aan dat zakelijke gebruikers of eindgebruikers niet gemakkelijk van het platform kunnen wisselen indien zij eenmaal bij een platform zijn aangesloten. Zakelijke gebruikers en eindgebruikers investeren in een platform door bijvoorbeeld een profiel aan te maken, aanbod of vraag te uploaden, zoekhistorie op te bouwen of bijvoorbeeld goede beoordelingen te verzamelen. Als deze investeringen (in tijd, geld maar ook moeite) substantieel zijn, kan een overstap naar een ander platform zoveel kosten met zich meebrengen dat een zakelijke gebruiker of een eindgebruiker daar al bij voorbaat vanaf ziet. Zie ook het paper van het CBS over platformen (2020, versie 4.0) voor meer uitleg over de kenmerken van meerzijdige markten en platformen.

10. DMA, p. 2 en overweging 12; Gerbrandy e.a., ASCOLA 2021 Conference 2021 omvat een bredere lijst van kenmerken, bijv. reputatieeffecten, gegevens- en Al-capaciteiten. 
afhankelijkheidsrelatie te reguleren door eerlijkheid en betwistbaarheid op digitale markten te bevorderen.

Aan de zakelijke kant van de markt levert de poortwachter kernplatformdiensten aan een zakelijke gebruiker, die van deze diensten afhankelijk is. ${ }^{11}$ Een poortwachter heeft vaak een dubbelrol waarbij hij de kernplatformdienst levert maar ook met zakelijke gebruikers concurreert op dat platform door soortgelijke diensten als de zakelijke gebruiker aan te bieden. Het gevaar is dat de poortwachter zijn eigen diensten op oneerlijke wijze promoot, waardoor potentiële belangenconflicten ontstaan. Ter illustratie, neem een appstore - een kernplatformdienst van een poortwachter die app-ontwikkelaars (zakelijke gebruikers) nodig hebben om hun consumenten te bereiken. ${ }^{12}$ Een poortwachter die een appstore exploiteert (zoals Apple of Google) kan zijn eigen apps via die appstore aanbieden, waardoor zakelijke gebruikers zoals app-ontwikkelaars in een bijzonder kwetsbare positie worden geplaatst. ${ }^{13}$

Aan de gebruikerszijde van de markt bedient de poortwachter rechtstreeks de eindgebruikers, zoals bijvoorbeeld Google of Apple doen als ze rechtstreeks in de appstore apps aanbieden aan eindgebruikers. ${ }^{14}$ Aangezien de poortwachters een stevig verankerde en duurzame positie hebben vergaard op digitale markten, kunnen eindgebruikers weinig anders doen dan te vertrouwen op hun kernplatformdiensten. ${ }^{15}$ Bovendien zijn eindgebruikers afhankelijk van de poortwachter om de diensten die door zakelijke gebruikers worden aangeboden te kunnen gebruiken. In het bovengenoemde voorbeeld zou de eindgebruiker met een iPhone afhankelijk zijn van de appstore van Apple om verschillende app-diensten te kunnen gebruiken. ${ }^{16}$

\section{De doelstellingen van de DMA}

De DMA wil zorgen voor betwistbare en eerlijke markten in de digitale sector, twee doelstellingen die het

11. Art. 2 lid 17 DMA.

12. Art. 2 lid 2 DMA: exhaustieve lijst van kernplatformdiensten. Appstores zijn kernplatformdiensten. Art. 2 lid 2 onder a bepaalt dat onlinetussenhandelsdiensten tot de kernplatformdiensten behoren. Voor de definitie van onlinetussenhandelsdiensten verwijst de DMA naar Verordening (EU) 2019/1150 van het Europees Parlement en de Raad van 20 juni 2019 ter bevordering van billijkheid en transparantie voor zakelijke gebruikers van onlinetussenhandelsdiensten (Platform-to-Business verordening). Voor die verordening gaf de Commissie appstores als voorbeeld van een onlinetussenhandelsdienst.

13. Besluit Commissie 27 juni 2017, zaak AT.39740 (Google Search (Shopping)); zaak AT.40462 (Amazon Marketplace), zaak aanhangig gemaakt op 17 juli 2019.

14. Art. 2 lid 16 DMA en overweging 13: in bepaalde omstandigheden moet het begrip 'eindgebruiker' ook gebruikers omvatten die traditioneel als zakelijke gebruikers worden beschouwd, maar in een bepaalde situatie geen gebruik maken van de diensten van het kernplatform om goederen of diensten te leveren aan andere eindgebruikers, zoals bijvoorbeeld bedrijven die voor hun eigen doeleinden gebruikmaken van cloud computing-diensten.

15. 'Wet digitale markten: zorgen voor eerlijke en open digitale markten', Europese Commissie, ec.europa.eu 15 december 2020.
Europese mededingingsrecht niet vreemd zijn. ${ }^{17}$ De DMA erkent deze overlap echter niet. Er wordt daarentegen gesteld dat doelstellingen worden nagestreefd die complementair zijn aan, maar verschillen van het mededingingsrecht, waarbij het mededingingsrecht tot doel heeft onvervalste mededinging op de markt te beschermen. ${ }^{18}$ Hoewel velen deze complexe en onduidelijke relatie met het mededingingsrecht bekritiseren, erkennen anderen dat de DMA en het mededingingsrecht zeer verschillende instrumenten zijn. ${ }^{19}$ De Commissie lijkt met de DMA de 'vereconomisering' van het

16. Het is mogelijk om de Apple appstore te omzeilen door apps te sideloaden op iOS. 'Sideloading' is het proces van het downloaden en installeren van apps op een mobiel apparaat vanaf een andere bron dan de officiële appstore, zoals een website of een app-winkel van een derde partij. In een rapport dat Apple in juni 2021 publiceerde, stelt Apple dat de praktijk zijn telefoons minder veilig en betrouwbaar zou maken voor gebruikers doordat de beveiliging van het iOS-platform wordt aangetast en gebruikers worden blootgesteld aan ernstige veiligheidsrisico's. Het rapport is een reactie op een door Epic aangespannen zaak tegen Apple, de DMA en Amerikaanse wetgevers, die stellen dat Apple gedwongen moet worden om toe te staan dat apps op iPhones worden gesideload. Zie Apple, 'Building a Trusted Ecosystem for Millions of Apps: The important role of App Store protections', 2021.

17. Art. 1 lid $1 \mathrm{DMA}$ en toelichting, p. 2-3. Volgens geleerden verschillen de doelstellingen van eerlijkheid en betwistbaarheid niet veel van de doelstellingen die door het Europese mededingingsrecht worden nagestreefd, en zij hebben gepleit voor een op eerlijkheid gebaseerd mededingingsrecht om de blinde vlekken van een economisch mededingingsrecht te verhelpen. Volgens hen is eerlijkheid, gedefinieerd als een gelijke kans voor iedereen, een van de grondbeginselen van het mededingingsrecht (zowel in de VS als in Europa). Zo weerspiegelt het Europese mededingingsrecht duidelijk rechtvaardigheidsoverwegingen, zoals blijkt uit zowel het verbod op misbruik door uitbuiting als het 'billijk aandeel voor de gebruikers'-criterium in art. 101 lid 3 Verdrag betreffende de werking van de Europese Unie (VWEU). Markten betwistbaar houden is altijd een doelstelling van het Europese mededingingsrecht geweest, indien men betwistbaarheid interpreteert als het openhouden van markten. De DMA vat betwistbaarheid echter ruimer op dan economen, namelijk door betwistbaarheid te begrijpen als de algemene bevordering van de mededinging. In die zin vertoont de doelstelling van betwistbaarheid van de DMA een grote overlap met de doelstellingen van het Europese mededingingsrecht. I. Lianos, 'Competition Law as a Form of Social Regulation', The Antitrust Bulletin 2020, afl. 1, p. 3-86; E.J. Hughes, 'The left side of antitrust: What fairness means and why it matters', Marquette Law Review 2009, p. 265-306; H. Schweitzer, 'The art to make gatekeeper positions contestable and the challenge to know what is fair: A discussion of the Digital Markets Acts Proposal', te verschijnen in Zeitschrift für Europäisches Privatrecht 2021.

18. De DMA bepaalt dat zij van toepassing is onverminderd het Europese mededingingsrecht. Zie DMA, overwegingen 9-10.

19. De overlap tussen het mededingingsrecht en de DMA is bekritiseerd: zie Schweitzer 2021 en Petit, 'The Proposed Digital Markets Act (DMA): A Legal and Policy Review', beschikbaar op SSRN 3843497, 2021. In Strengthening the Digital Markets Act and Its Enforcement 2021 vermelden Frankrijk, Duitsland en Nederland ook uitdrukkelijk dat de verhouding tussen de DMA en het Europese mededingingsrecht nader moet worden gepreciseerd. Zij stellen dat '(...) de verordening van toepassing is naast het mededingingsrecht. Wij betwijfelen of het voorstel van de Commissie alle hierdoor opgeworpen vragen volledig beantwoordt. Het is van het grootste belang dat het nieuwe instrument de bestaande instrumenten (d.w.z. het Europese en nationale mededingingsrecht) daadwerkelijk aanvult, in plaats van ze te verzwakken of te vervangen. Aangezien met de DMA en het mededingingsrecht complementaire en nabije doelstellingen moeten worden nagestreefd, mogen beide reeksen regels elkaar niet hinderen maar moeten zij elkaar juist aanvullen, met alle synergie-effecten van dien'. Over het feit dat het verschillende instrumenten zijn: zie P. Ibáñez Colomo, 'The Draft Digital Markets Act: a legal and institutional analysis', Colomo, beschikbaar op SSRN 3790276, 2021 
mededingingsrecht in het afgelopen decennium te nuanceren waarbij de DMA als regelgevend instrument de mededinging als proces beschermt. ${ }^{20}$ Alvorens in te gaan op de bescherming van zakelijke gebruikers en eindgebruikers, verdienen de doelstellingen van de DMA en hun onderlinge verhouding nadere bespreking.

Eerlijkheid is in de DMA niet expliciet gedefinieerd, behalve dat zakelijke gebruikers en eindgebruikers een 'eerlijke commerciële relatie' met de poortwachters moeten kunnen aangaan, die leidt tot 'eerlijke economische resultaten'.21 Uit de verbodsbepalingen en verplichtingen in de DMA blijkt dat eerlijkheid zowel een procedurele functie heeft - het waarborgen van eerlijke deelname aan kernplatformdiensten of concurrentie met kernplatformdiensten - als een distributieve functie - het waarborgen van een eerlijk aandeel in de economische voordelen in de waardeketen. ${ }^{22}$ De DMA legt inhoudelijk de nadruk op de procedurele functie van eerlijkheid en reguleert de manier waarop poortwachters zakelijke gebruikers en eindgebruikers moeten behandelen. ${ }^{23}$ Door een eerlijke deelname te waarborgen streeft de DMA naar eerlijke economische resultaten, of distributieve eerlijkheid. Waar een 'vereconomiseerd' mededingingsrecht eerlijke economische resultaten beperkt zou opvatten als het voorkomen van hogere prijzen, lagere kwaliteit, minder keuze en innovatie, suggereert de DMA dat er ruimte is voor een ruimere interpretatie van eerlijkheid door te erkennen dat bescherming moet worden geboden aan 'publieke belangen die verder gaan dan concurrentie of economische overwegingen. ${ }^{24}$

Voor zakelijke gebruikers betekent eerlijkheid dat zij binnen het platformecosysteem van de poortwachter kunnen concurreren en innoveren zonder te moeten voldoen aan oneerlijke voorwaarden. ${ }^{25}$ Dit doet denken aan de reeks zaken over online hotelboekingen waarbij hotels

20. Zij zullen dit evenwel niet doen binnen de sfeer van het mededingingsrecht, maar met een afzonderlijk en duidelijk verschillend regelgevend instrument. Zie Schweitzer 2021.

21. DMA, overwegingen 2 en 5 . Het feit dat zowel eerlijkheid als betwistbaarheid niet in de DMA zijn gedefinieerd, is bekritiseerd en zou de DMA tot minder doeltreffende regelgeving maken. Zie G.S. Crawford e.a., 'Fairness and Contestability in the Digital Markets Act', Yale Tobin Center For Economic Policy 2021, afl. 3, waarin wordt betoogd dat de platformeconomie leidt tot 'oneerlijke' uitkomsten waarbij gebruikers niet worden beloond voor hun bijdrage aan het succes van het platform. Regelgeving moet erop gericht zijn deze verstoring te corrigeren. Indien goed uitgevoerd, kan regelgeving die gebaseerd is op de begrippen eerlijkheid en betwistbaarheid ook bevorderlijk zijn voor innovatie.

22. Er kunnen veel verschillende opvattingen over eerlijkheid bestaan, waardoor dit een simplificatie van het begrip eerlijkheid is. Voor andere conceptualiseringen: zie D. Gerber, 'Fairness competition law: European and US experience', in: Conference on Fairness and Asian Competition Laws, 2004 en Hughes 2009. Voor een bespreking van andere opvattingen van eerlijkheid in de DMA, zie Schweitzer 2021 en Petit 2021.

23. In DMA, preambule lid 5, wordt expliciet vermeld dat zij streeft naar eerlijke economische resultaten.

24. DMA, Toelichting, p. 3. Op pagina 1 van de Toelichting, wordt gesteld dat de regelgevende interventie gerechtvaardigd is met 'inefficiënte situaties in de digitale sector zoals hogere prijzen, lagere kwaliteit, minder keuze en minder innovatie ten nadele van de Europese consumenten'.

25. 'Wet digitale markten: zorgen voor eerlijke en open digitale markten', Europese Commissie, ec.europa.eu, 15 december 2020. (zakelijke gebruikers) geen kamers mochten verhuren tegen gunstigere tarieven aan eindgebruikers buiten het platform van Booking.com. ${ }^{26}$ Uiteindelijk is bepaald dat hotels wel degelijk hun kamers mochten aanbieden tegen een gunstiger tarief, hetgeen leidde tot enige discussie. Het zou immers oneerlijk zijn voor Booking.com om zakelijke gebruikers te laten profiteren van de voordelen van het platform zonder dat het platform daaraan bepaalde voorwaarden kan stellen. Toch lijkt de Commissie er nu expliciet voor te kiezen om de positie van zakelijke gebruikers te bevoordelen boven die van poortwachters. Wanneer deze 'eerlijkheid' ten opzichte van zakelijke gebruikers wordt gewaarborgd, zouden eindgebruikers bijgevolg meer en betere diensten kunnen kiezen, meer mogelijkheden hebben om desgewenst van aanbieder te veranderen, en eerlijkere prijzen krijgen. ${ }^{27}$ Voor eindgebruikers bevat de DMA een aantal bepalingen die een eerlijke commerciële relatie tussen de eindgebruiker en de poortwachter rechtstreeks bevorderen. Zoals hieronder zal worden besproken stellen bepalingen zoals het waarborgen van gegevensportabiliteit in artikel 6 , onder $\mathrm{h}$, eindgebruikers in staat zelf te bepalen met welke dienstverleners zij zaken willen doen en wanneer. Zij bepalen niet de eerlijkheid van de resultaten, maar bevorderen de eerlijke deelname van deze eindgebruikers aan het platform van de poortwachters.

Het bevorderen van eerlijke relaties tussen poortwachters en zijn zakelijke gebruikers en eindgebruikers is nauw verbonden met de tweede doelstelling van de DMA: zorgen voor betwistbare digitale markten. Hoewel betwistbaarheid niet in de DMA wordt gedefinieerd, beschrijven economen een betwistbare markt als een situatie waarin een markt nog steeds efficiënt is met slechts één of enkele aanwezige ondernemingen omdat door lage toetredingsdrempels er een reële dreiging is dat nieuwe aanbieders de markt zullen betreden. ${ }^{28}$ Als gevolg van extreme schaalvoordelen, afhankelijkheid van zowel zakelijke gebruikers als eindgebruikers van poortwachters, lock-in-effecten, een gebrek aan multihoming, verticale integratie, en datagestuurde voordelen, zijn digitale markten niet betwistbaar omdat het betreden van de markt op korte termijn moeilijk of onmogelijk is gemaakt. ${ }^{29}$

Op een betwistbare digitale markt is het voor concurrenten gemakkelijker om de markt te betreden en con-

26. Deze besluiten van de nationale mededingingsautoriteiten van Frankrijk, Duitsland, Italië en Zweden in 2015 hebben de Commissie ertoe aangezet art. 5 onder b en c op te nemen in de DMA (2020), waarin wordt bepaald dat poortwachters zakelijke gebruikers toe moeten laten producten aan te bieden, aanbiedingen aan eindgebruikers te promoten en contracten met eindgebruikers te sluiten zonder gebruik te maken van de kernplatformdiensten van de poortwachter.

27. 'Wet digitale markten: zorgen voor eerlijke en open digitale markten', Europese Commissie, ec.europa.eu, 15 december 2020.

28. Zie R.S. Khemani \& D.M. Shapiro, Glossary of Industrial Organisation Economics and Competition Law (in opdracht van het Directorate for Financial, Fiscal and Enterprise Affairs) OECD 1993. Een markt is betwistbaar wanneer er geen belemmeringen zijn voor het betreden of verlaten van de markt, wanneer alle ondernemingen toegang hebben tot dezelfde productietechnologie en wanneer er perfecte informatie over de prijzen is. Dit is niet het geval op de digitale markt.

29. DMA, preambule lid 1. 
currerende kernplatformdiensten of andere diensten aan te bieden. Als we het voorbeeld van de appstore nemen, zouden andere bedrijven dan Apple en Google in staat zijn een concurrerende appstore aan te bieden of zou het voor zakelijke gebruikers gemakkelijker zijn een nieuwe app in de appstore aan te bieden. Doordat in betwistbare digitale markten de toetredingsdreiging een concurrentiedruk uitoefent op poortwachters, worden zij gedwongen om eerlijker te werk te gaan ten opzichte van zowel zakelijke gebruikers als eindgebruikers. De DMA verlaagt expliciet de toetredingsdrempels voor nieuwe bedrijven om concurrerende producten of diensten aan te bieden (zoals concurrerende appstores). De DMA gaat echter veel verder dan het verlagen van toetredingsdrempels en stelt zelfs nieuwe gedragsregels vast voor poortwachters zodat bestaande bedrijven gemakkelijker met hen kunnen concurreren. ${ }^{30}$ De term 'betwistbaarheid' in de DMA neigt daarmee naar de doelstelling van het Europese mededingingsrecht om onvervalste mededinging te waarborgen. Deze overlap met het mededingingsrecht is uiteraard te bekritiseren maar lijkt tegelijkertijd een voorwaarde om de door de DMA beoogde eerlijkheid te waarborgen. ${ }^{31}$

De DMA legt de poortwachter verplichtingen en verboden op om eerlijke en betwistbare markten voor zowel zakelijke gebruikers als eindgebruikers te garanderen. Artikel 5 en 6 bevatten de belangrijkste verplichtingen en verboden en zijn onderverdeeld in twee categorieën: zelfuitvoerende verplichtingen uit artikel 5 en verplichtingen die nader moeten worden gespecificeerd in een regelgevingsdialoog tussen de Commissie en de poortwachters in artikel $6 .{ }^{32} \mathrm{Wij}$ zullen hierna bekijken of deze bepalingen in de DMA de eindgebruiker daadwerkelijk beschermen.

\section{Het spectrum van eindgebruikersbescherming}

Verscheidene belanghebbenden zijn bezorgd dat de DMA eindgebruikers onvoldoende bescherming biedt. ${ }^{33}$ Terwijl de DMA probeert om eerlijke economische relaties tussen eindgebruikers, zakelijke gebruikers en de poortwachter te bevorderen, lijkt het erop dat de meeste bepalingen gericht zijn op de directe bescherming van zakelijke gebruikers. Dit heeft geleid tot zorgen over de bescherming van eindgebruikers. ${ }^{34}$ In dit onderdeel gaan wij na of deze zorgen gerechtvaardigd zijn. Wij stellen vast dat de bepalingen in de DMA kunnen worden gevisualiseerd als een opeenvolgende reeks of spectrum aan eindgebruikersbescherming tegen oneerlijke praktijken van poortwachters. Aan het ene uiterste van het spectrum biedt de DMA de eindgebruikers directe bescherming en voordelen. In het midden vinden wij bepalingen die bedoeld zijn om zakelijke gebruikers te beschermen, maar waarvan de eindgebruikers indirect ook profiteren. Aan het andere uiterste van het spectrum biedt de DMA bepaalde bescherming voor eindgebruikers juist niet.

Directe voordelen voor eindgebruikers

Verscheidene verplichtingen voor poortwachters beschermen de eindgebruiker rechtstreeks, zoals verplichtingen die de eindgebruiker controle geven over zijn persoonsgegevens die de poortwachter verwerkt. Ten eerste mag de poortwachter zonder toestemming van eindgebruikers hun persoonsgegevens uit verschillende bronnen niet langer combineren of hen aanmelden op andere diensten van de poortwachter. ${ }^{35}$ Poortwachters moeten hun eindgebruikers dus in staat stellen vrij te kiezen voor deze opties door ook een minder gepersonaliseerd alternatief an te bieden. ${ }^{36}$ Ten tweede zijn poortwachters nu ook verplicht eindgebruikers de instrumenten te verschaffen voor real-time, continue en effectieve gegevensoverdraagbaarheid. ${ }^{37}$ Deze bepalingen beschermen eindgebruikers tegen oneerlijk gebruik van hun persoonsgegevens waar poortwachters vaak
30. Zie bijvoorbeeld de regels inzake specifieke poortwachters die FRANDvoorwaarden moeten aanbieden (art. 6 lid 1 onder j en k DMA), die aanvallen op de gevestigde positie van de poortwachter zullen vergemakkelijken en de concurrentie op het platform zelf zullen bevorderen. Voor een uitgebreidere discussie over betwistbaarheid en de rol daarvan in de DMA, zie Schweitzer 2021.

31. Zie Schweitzer 2021 en Petit 2021.

32. Deze regelgevingsdialoog is bedoeld om de Commissie in specifieke gevallen met specifieke poortwachters in staat te stellen doeltreffende en evenredige maatregelen te nemen voor de tenuitvoerlegging van de verplichtingen van art. 6 . Het feit dat er geen regelgevingsdialoog mogelijk is voor de verbodsbepalingen van art. 5 zou erop kunnen wijzen dat die verbodsbepalingen een rigider regime creëren dan die van art. 6. Zie DMA, overweging 29.
33. Zie Advies 2/2021 van de Europese Toezichthouder voor gegevensbescherming (10 februari 2021), Voorstel voor een wet digitale markten; Ontwerpverslag BEREC BoR (21) 34 van het Orgaan van Europese regelgevende instanties voor elektronische communicatie (11 maart 2021), Over de regelgeving ex ante voor digitale poortwachters; Position Paper BEUC-X-2021-030 van de Europese Consumentenorganisatie (1 april 2021), Voorstel voor een wet digitale markten.

34. Er zijn tien bepalingen die rechten voor zakelijke gebruikers bevatten en zeven bepalingen die rechten voor eindgebruikers bevatten. Zie K. Coates, 'The EU's draft Digital Markets Act (DMA): classifying the obligations', twentyfirstcenturycompetition.com, 1 februari 2021.

35. Art. 5 onder a DMA en overweging 36.

36. DMA, overweging 36.

37. Art. 6 lid 1 onder h DMA. 
gebruik van maken om hen aan de kernplatformdiensten te binden. ${ }^{38}$

Ook al erkennen belangenorganisaties dat deze bepalingen een eerste stap zijn naar een eerlijke economische relatie tussen poortwachters en eindgebruikers, zij vragen zich ook af of de eindgebruiker niet baat had gehad bij meer bescherming. Zo verwelkomt de Europese Toezichthouder voor gegevensbescherming (EDPS) het verbod op het combineren van gegevensbronnen, maar de EDPS merkt ook op dat volgens de Algemene verordening gegevensbescherming (AVG) de toestemming van een individu nu al nodig is voor het combineren van persoonsgegevens tussen diensten. ${ }^{39}$ De vraag is dan of deze bepaling daadwerkelijk extra voordelen voor de eindgebruiker oplevert. Ook het recht op gegevensoverdraagbaarheid is al vastgelegd in artikel 20 van de AVG, en de DMA specificeert daarbij niet duidelijk wie het recht op gegevensoverdraagbaarheid heeft en welke gegevens kunnen of moeten worden overgedragen. ${ }^{40}$

Er zijn andere bepalingen die uitsluitend rechten toekennen aan eindgebruikers, zoals het recht om voorgeinstalleerde softwaretoepassingen te verwijderen (art. 6 lid 1 onder $b$ ), het recht om softwaretoepassingen of appstores van derden te installeren (art. 6 lid 1 onder c) of het verbod voor poortwachters om de mogelijkheid van eindgebruikers om over te stappen naar andere softwaretoepassingen en -diensten technisch te beperken (art. 6 lid 1 onder e). Ook al is de eindgebruiker de primaire begunstigde van deze bepalingen, wij zijn van mening dat zakelijke gebruikers ook baat hebben bij deze rechten omdat eindgebruikers eerder geneigd zullen zijn om op hun producten en diensten over te stappen. Zo beschermt het recht voor eindgebruikers om voorgeïnstalleerde softwaretoepassingen te verwijderen zowel de zakelijke gebruiker als de eindgebruiker, aangezien de vrije keuze van eindgebruikers wordt beschermd. ${ }^{41}$ Als eindgebruikers minder geneigd zijn de voorgeïnstalleerde apps te gebruiken en gemakkelijker kunnen overstappen op concurrerende softwaretoepassingen, komt dit ook de zakelijke gebruiker ten goede. Deze gunstige effecten worden versterkt door de verplichting voor de poortwachter om eindgebruikers toe te

38. Hierbij moet worden opgemerkt dat deze verplichtingen weliswaar rechten verlenen aan en rechtstreeks ten goede komen aan de eindgebruiker, maar dat zij indirect ten goede komen aan de zakelijke gebruiker. Bijvoorbeeld art. 5 onder a en art. 6 lid 1 onder h zijn bedoeld om een einde te maken aan het datagedreven voordeel van poortwachters ten opzichte van hun zakelijke gebruikers en andere concurrenten. Door te voorkomen dat eindgebruikers aan een bepaalde technologie komen vast te zitten, komen deze bepalingen ook zakelijke gebruikers ten goede, aangezien eindgebruikers minder moeite hebben om op een alternatief over te schakelen zodra een concurrent de markt betreedt.

39. Advies 2/2021 van de Europese Toezichthouder voor gegevensbescherming (10 februari 2021), Voorstel voor een digitale-marktwet, p. 10.

40. Advies 2/2021 van de Europese Toezichthouder voor gegevensbescherming (10 februari 2021), Voorstel voor een digitale-marktwet, p. 11.

41. Voorgeïnstalleerde apps en standaardopties zijn zeer krachtige instrumenten om datagedreven netwerkeffecten te bewerkstelligen. De keuze van de gebruiker wordt daardoor aanzienlijk beïnvloed door standaardopties die zijn geïntegreerd in de producten en diensten die hij gebruikt. Zie J. Krämer, D. Schnurr \& S. Micova, The role of data for digital markets contestability: case studies and data access remedies, Brussel: Centre on Regulation in Europe 2020, p. 85. staan andere softwaretoepassingen te installeren en daarnaar over te stappen. ${ }^{42}$

Indirecte voordelen voor eindgebruikers

De zorgen over eindgebruikersbescherming vloeien voornamelijk voort uit het feit dat veel bepalingen in de DMA de zakelijke gebruiker als de primaire begunstigde benoemen. De bepalingen richten zich dus op de bescherming van zakelijke gebruikers tegen de oneerlijke praktijken van poortwachters. Echter, waar de doelstellingen van eerlijkheid en betwistbaarheid nauw met elkaar verbonden zijn, geldt dat ook voor de bescherming van zakelijke gebruikers en eindgebruikers. Bepalingen die een eerlijke economische relatie tussen zakelijke gebruikers en poortwachters en de betwistbaarheid van digitale markten waarborgen, kunnen derhalve indirect ook de eindgebruiker beschermen.

De verplichting voor poortwachters om zakelijke gebruikers toegang te verlenen tot appstores op basis van eerlijke en niet-discriminerende algemene voorwaarden ('FRAND') voorwaarden, is een van die verplichtingen die ogenschijnlijk alleen bescherming en rechten biedt aan zakelijke gebruikers. ${ }^{43}$ Eindgebruikers hebben echter ook baat bij deze bepaling. Deze verplichting is in de DMA opgenomen nadat appontwikkelaars klaagden over de hoge commissies die poortwachters rekenden voor appaankopen in appstores en aankopen in apps zelf. Tevens klaagden zij over het gebrek aan kennisgeving van technische wijzigingen in de appstores, waardoor appontwikkelaars hun apps op korte termijn moesten aanpassen. ${ }^{44}$ Deze praktijken hadden een directe invloed op de (doorberekende) prijs en de functionaliteit van apps voor eindgebruikers. Door ervoor te zorgen dat appontwikkelaars hun apps in appstores kunnen aanbieden op basis van FRAND-voorwaarden, gaat de eindgebruiker zowel qua prijs als functionaliteit erop vooruit.

Poortwachters verplichten om onder FRAND-voorwaarden diensten aan te bieden aan zakelijke gebruikers en derden is een terugkerend thema in de DMA. Zo moeten poortwachters ook FRAND-voorwaarden toepassen op de rangschikking op hun kernplatformdiensten van diensten en producten van derden. ${ }^{45}$ Deze bepaling doet denken aan de Google Shopping-zaak waar Google zijn eigen Google Shopping-producten hoger

42. Art. 6 lid 1 onder $c$ en e DMA.

43. Art. 6 lid 1 onder $k$ DMA.

44. Commission Staff Working Document on DMA, p. 59 en 84; zie voor de klachten van appontwikkelaars bijvoorbeeld de klacht van Spotify bij de Europese Commissie. Deze klacht werd gesteund door andere appontwikkelaars zoals Tile, Telegram, Epic Games en de Coalition for App Fairness. Deze klachten leidden ertoe dat de Commissie een mededeling van punten van bezwaar naar Apple stuurde over zijn in-app aankoopsysteem, zie Apple App Store Practices (music streaming) (zaak AT.40437). Procedure aanhangig gemaakt op 16 juni 2020. In Duitsland en Spanje heeft de privacygroep nyob bij de mededingings- en privacyautoriteiten klachten ingediend tegen Apple naar aanleiding van de nieuwe eis van Apple om toestemming te krijgen van gebruikers voor het verzamelen van hun random gegenereerde identificatie in een iOSomgeving (Identifier for Advertisers, IDFA). Zie noyb, 'noyb dient klachten in tegen Apple's tracking code "IDFA"', noyb. eu, 16 november 2020.

45. Art. 6 lid 1 onder d DMA. 
rangschikte dan producten van derden. ${ }^{46}$ Eindgebruikers hebben de neiging alleen naar de eerste pagina met resultaten te kijken, waardoor zij niet naar de goedkoopste of beste resultaten werden geleid, maar naar de producten van Google. Vergelijkbare problemen kunnen zich voordoen op Amazon Marketplace en appstores, waar de poortwachter zowel de kernplatformdienst levert als op dat platform opereert. FRAND-voorwaarden voor zakelijke gebruikers moeten er dan voor zorgen dat eindgebruikers het beste aanbod krijgen.

Deze en andere bepalingen beschermen zakelijke gebruikers wanneer zij op de kernplatformdienst van een poortwachter opereren door ervoor te zorgen dat de concurrentie op de kernplatformdienst niet op oneerlijke wijze wordt verstoord. ${ }^{47}$ Ondernemingen concurreren echter niet alleen met poortwachters 'op' hun kernplatformdiensten, maar trachten soms ook direct met de poortwachter te concurreren door met een nieuwe kernplatformdienst de markt te betreden. Dit is echter niet gemakkelijk omdat de digitale markten niet betwistbaar zijn. Enkele bepalingen in de DMA zijn erop gericht om deze betwistbaarheid te bevorderen en deze directe concurrentie wel mogelijk te maken. ${ }^{48}$

Een van die bepalingen schrijft voor dat poortwachters FRAND-toegang moeten verlenen aan derden tot gegevens over rangschikkingen, zoekopdrachten, clicks en weergaven door eindgebruikers, terwijl een andere bepaling poortwachters ertoe verplicht concurrerende appstores toe te staan. ${ }^{49}$ In theorie kan dit leiden tot een alternatieve zoekmachine met een vergelijkbare kwaliteit als die van Google of een alternatieve app-store van vergelijkbare kwaliteit als die van Apple en Google. Hoewel deze bepalingen uitsluitend zakelijke gebruikers lijken te beschermen en te begunstigen door de betwistbaarheid van digitale markten te vergroten, denken wij dat dit indirect ten goede kan komen aan eindgebruikers. Voor concurrenten van poortwachters zal het immers gemakkelijker worden de markt te betreden, wat ervoor zorgt dat een potentiële concurrent realistischer wordt en dus

46. Besluit Commissie 27 juni 2017, zaak AT.39740 (Google Search (Shopping)).

47. Andere bepalingen zijn onder meer art. 5 onder c, dat poortwachters verplicht om toe te staan aan zakelijke gebruikers dat zij met via het platform verworven eindgebruikers contracten afsluiten, ongeacht of zij daarvoor gebruikmaken van de kernplatformdiensten van de poortwachter, art. 5 onder e en $f$ dat ervoor zorgt dat poortwachters hun identificatiediensten of andere diensten niet koppelen aan het gebruik van hun kernplatformdienst, art. 6 lid 1 onder $f$, dat poortwachters ertoe verplicht toegang tot en operabiliteit met dezelfde besturingssystemen te garanderen als die welke zij gebruiken wanneer zij met zakelijke gebruikers concurreren.

48. DMA, overweging 3, 36 en 37

49. Art. 6 lid 1 onder j en art. 6 lid 1 onder c DMA. Er zijn alternatieven voor Google Search, zoals Bing, maar deze alternatieven lijken van mindere kwaliteit te zijn dan Google Search. Dit verschil in kwaliteit zou verklaard kunnen worden door een verschil in kwaliteit van gegevens of algoritmen. Het lijkt erop dat de Commissie het voordeel van de kwaliteit van de gegevens voor Google wil wegnemen door concurrenten toegang te geven tot de gegevens over rangschikkingen, zoekopdrachten, clicks en weergaven door eindgebruikers van Google Search. Er blijft echter nog steeds een verschil in zoekalgoritmen tussen Google Search en haar concurrenten. Of art. 6 lid 1 onder j werkelijk helpt om de kernplatformconcurrentie voor zoekmachines te verbeteren valt daarom nog te bezien. de concurrentiedruk op poortwachters zal verhogen. Hopelijk beweegt deze (realistische) concurrentiedruk de poortwachter ertoe om eindgebruikers eerlijker te behandelen, ook als de concurrentie de markt nog niet heeft betreden. Wanneer een concurrent de markt daadwerkelijk betreedt, krijgen eindgebruikers meer keuze, hetgeen ook hen ten goede zal komen.

Kortom, deze bepalingen lijken dus gericht op de bescherming van zakelijke gebruikers, maar kunnen tevens de eindgebruiker beschermen. Wellicht zijn de zorgen over de bescherming van eindgebruikers dus niet gerechtvaardigd. Wij stellen echter wel vast dat er nog steeds een lacune is in de bescherming van de eindgebruiker, welke wij hierna zullen bespreken.

\section{Een gemiste kans voor de bescherming van de eindgebruiker}

Aan de andere zijde van het spectrum ligt volgens ons een gemiste kans voor de DMA om eindgebruikers verder te beschermen tegen poortwachters. Poortwachters kunnen misbruik maken van de gedragsneigingen van eindgebruikers om de in de artikelen 5 en 6 neergelegde verplichtingen en bepalingen te omzeilen. ${ }^{50}$ Artikel 11 lid 1 DMA probeert dit al deels te voorkomen door te bepalen dat de tenuitvoerlegging van artikel 5 en 6 'niet wordt ondermijnd door gedragingen van de onderneming waartoe de poortwachter behoort, ongeacht of dit gedrag van contractuele, commerciële, technische of andere aard is' ${ }^{51}$ In feite wordt hiermee van de poortwachters verwacht dat zij zorgen voor 'compliance by design' met deze wettelijke bepalingen. Echter zwijgt deze verplichting over de kwaliteit van de keuze die aan de eindgebruikers moet worden geboden. ${ }^{52}$

Het al maar toenemende onderzoek naar menselijk gedrag heeft aangetoond dat de besluitvorming van mensen wordt beïnloed door omgevings- en cognitieve beperkingen. ${ }^{53}$ Het ontwerp van hun keuzeomgeving, waartoe digitale interfaces behoren, heeft grote invloed op hoe mensen zullen reageren op de gepresenteerde informatie en, uiteindelijk, hoe zij zich zullen gedragen. Door de gedragsneigingen van eindgebruikers te benutten, kunnen poortwachters hen sturen naar voorspelbare uitkomsten. ${ }^{54}$ Poortwachters zijn goed gepositioneerd om een groot aantal eindgebruikers te bereiken en hen grootschalig en systematisch te beinvloeden, waardoor

50. Position Paper BEUC-X-2021-030; een andere aanbeveling is om zorgvuldiger aandacht te besteden aan de positionering van defaults. Ontwerp BEREC-verslag BoR (21) 34, p. 21 doet een soortgelijke aanbeveling in verband met art. 6 onder $d$, dat een oneerlijke rangschikking van diensten en producten verbiedt. Een expliciete vermelding van het effect van de standaardinstelling op de keuze van de gebruikers ontbreekt.

51. Art. 11 lid 1 DMA.

52. DMA, overweging 58

53. H.A. Simon, 'A behavioural model of rational choice', The quarterly journal of economics 1955, afl. 1, p. 99-118; D. Kahneman \& A. Tversky, 'Judgment under uncertainty: Heuristics and biases', Science 1974, afl. 185, p. 1124-1131; D. Kahneman, Thinking, fast and slow, Londen: Penguin Books 2011.

54. R.H. Thaler \& C.R. Sunstein, Nudge: Improving Decisions About Health, Wealth, and Happiness, New York: Penguin Putnam 2009. 
zij hun verantwoordelijkheden ten opzichte van de eindgebruiker kunnen omzeilen.

Een van die beïnloedingstechnieken zijn 'dark patterns', die verwijzen naar 'gebruikersinterfaces die zodanig zijn ontworpen dat zij een negatieve invloed uitoefenen op de gebruiker, en hem ertoe brengen een door de ontwerper gewenste beslissing te nemen'. ${ }^{55}$ Het zijn geen bugs, maar zorgvuldig uitgewerkte interface-ontwerpen die gebruikmaken van een gedegen begrip van de menselijke psychologie om voordeel te behalen bij de eindgebruikers. ${ }^{56}$ Dark patterns zijn vaak ondoorzichtig: ze kunnen informatie over beschikbare opties verbergen, ze zijn vaak moeilijk te vinden en dus moeilijk om te bestrijden, of ze kunnen opties op een overdreven ingewikkelde manier presenteren, vaak met het doel om frictie te creëren. ${ }^{57}$ Gezien hun ondoorzichtige en manipulatieve aard, kunnen dark patterns worden gebruikt om de effectiviteit van de verbodsbepalingen en verplichtingen van artikel 5 en 6 DMA te omzeilen. Terwijl bijvoorbeeld artikel 5 onder a DMA de poortwachter verplicht de toestemming van de eindgebruiker te verkrijgen voor het combineren van zijn persoonsgegevens van platformdiensten, kan via 'privacy Zuckering' deze verplichting worden omzeild. Deze techniek, in het verleden vaak gebruikt door Facebook, zet de eindgebruiker ertoe aan om meer informatie te delen dan hij van plan was of wil. ${ }^{58}$

Het is niet duidelijk of de anti-omzeilingsbepaling van artikel 11 ruim genoeg is om deze gedragstechnieken tegen te gaan. Dark patterns worden hoogstwaarschijnlijk gebruikt in situaties waarin eindgebruikers een keuze moeten maken die verband houdt met een specifieke verplichting van de poortwachter, zoals koppelverkoop van producten of installatie- en verwijderopties. Zolang

55. Autoriteit Consument \& Markt (ACM), Bescherming van de online consument. Grenzen aan online beïnvloeding, 2019, p. 51; A. Mathur e.a., 'Dark patterns at scale: Findings from a crawl of $11 \mathrm{~K}$ shopping websites', Proceedings of the ACM on Human-Computer Interaction 2019, p. 1-32. Andere definities zijn onder meer: $\mathrm{H}$. Bringnull, 'Dark Patterns are tricks used in websites and apps that make you do things that you didn't mean to, like buying or signing up for something', darkpatterns.org 2010: 'Dark Patterns are tricks used in websites and apps that make you do things that you didn't mean to, like buying or signing for something.' G. Conti \& E. Sobiesk, 'Malicious interface design: exploiting the user', Proceedings of the 19th international conference on World wide web 2010, p. 271-280 beschrijven ze als: 'interfaces die gebruikers manipuleren, uitbuiten of aanvallen'.

56. M. Fansher, S.S. Chivukula \& C.M. Gray, '\#darkpatterns: UX Practitioner Conversations About Ethical Design', Extended Abstracts of the 2018 CHI Conference on Human Factors in Computing Systems 2018, p. 1-6.

57. Bringnull 2010. Het is belangrijk op te merken dat er tot op heden verschillende soorten dark patterns zijn geïdentificeerd, waarbij enkele van de meest uitputtende studies tot op heden wijzen op zeven categorieën: sluipen, urgentie, misleiding, sociaal bewijs, schaarste, obstructie en gedwongen actie. Zie Mathur e.a., p. 12.

58. NB Verschillende studies tot nu toe waren gericht op dark patterns die worden gebruikt om gegevensbeschermingsbepalingen te omzeilen, zie onder meer: M. Nouwens e.a., 'Between scripts and applications: Computational media for the frontier of nanoscience', Proceedings of the $2020 \mathrm{CHI}$ conference on human factors in computing systems 2020, p. 1-13; C.M. Gray e.a., 'Dark Patterns and the legal requirements of consent banners: an interaction criticism perspective', Proceedings of the $2021 \mathrm{CHI}$ Conference on Human Factors in Computing System 2021, p. 1-18. eindgebruikers een keuze wordt voorgelegd, wordt blijkbaar aan de verplichting voldaan. Hierbij wordt niets bepaald over de kwaliteit van de keuze. De presentatie van keuzes kan de kwaliteit van de besluitvorming van eindgebruikers beïnvloeden en uiteindelijk hun gedrag sturen, wat leidt tot aantasting van de mogelijkheid zinvolle keuzes te maken. ${ }^{59}$ Aangezien dark patterns vaak heimelijk zijn en eindgebruikers niet weten dat zij worden gestuurd, is het wenselijk niet alleen waarborgen in te bouwen tegen een bevooroordeelde presentatie van keuzes, maar ook de eindgebruikers op een duidelijke en ondubbelzinnige manier te wijzen op de keuzes die worden gemaakt in het vormgeven van de keuzeomgeving door de poortwachter. ${ }^{60}$ De huidige formulering van de bepaling is niet eenduidig en benadeelde partijen zouden via een langdurig proces van bewijsvergaring en procesvoering de strijd moeten aangaan met mogelijk schadelijk gedrag van poortwachters. Dit maakt het gemakkelijker voor poortwachters om de verplichtingen en verbodsbepalingen te omzeilen. De DMA laat dus een kans liggen door geen duidelijke verplichting voor de poortwachter in te voeren om eindgebruikers te presenteren met onbevooroordeelde keuze en op een duidelijke en ondubbelzinnige manier te wijzen op de keuzes die worden gemaakt in het vormgeven van de keuzeomgeving. ${ }^{61}$

\section{Conclusie}

In dit artikel hebben wij onderzocht in welke mate eindgebruikers binnen de DMA kunnen te profiteren van een eerlijke en betwistbare digitale sector. De doelstellingen van eerlijkheid en betwistbaarheid zijn even nauw met elkaar verbonden als de posities van poortwachters, zakelijke gebruikers en eindgebruikers. Hoewel het moeilijk is onderscheid te maken tussen bepalingen die de zakelijke gebruiker beschermen en bepalingen die (indirect) ook de eindgebruiker beschermen, stellen wij vast dat de verplichtingen en verboden voor poortwachters in de DMA verschillende niveaus van eindgebruikersbescherming biedt. Deze niveaus kunnen worden gevisualiseerd als een spectrum. Aan het ene uiterste van het spectrum bieden bepalingen rechtstreekse

59. J. Susskind, Future politics: Living together in a world transformed by tech, Oxford: Oxford University Press 2018, p. 142-143.

60. De Groenen/EVA, 'Laat uw stem horen over de Digital Markets Act (DMA)', greens-efa.eu 2021

61. Wij erkennen dat het moeilijk is de eindgebruiker te beschermen tegen dark patterns. Toch is de eerste stap om dit te doen, te ontdekken wanneer en hoe dark patterns worden gebruikt. Het BEUC beveelt aan om in art. 19 lid 1 DMA op te nemen dat de Commissie niet alleen toegang moet krijgen tot databases en algoritmes van ondernemingen, maar ook tot hun A/B-testing. A/B-testing is een methode voor gebruikerservaring waarbij twee varianten worden getest om na te gaan welke keuzes gebruikers maken. Deze tests leggen meestal bloot welke dark patters mogelijk worden ingezet door een bedrijf. Begrijpen hoe bedrijven deze patronen inzetten, is de eerste stap in toekomstige regelgeving en handhaving. Zie: Position Paper BEUC-X-2021-030 van de Europese Consumentenorganisatie (1 april 2021), Voorstel voor een wet digitale markten. 
bescherming aan eindgebruikers, in het midden profiteren de eindgebruikers indirect van de bescherming die aan de zakelijke gebruikers wordt geboden, en aan het andere uiterste laat de DMA wellicht een kans voor eindgebruikersbescherming liggen.

Bepalingen die rechtstreeks de eindgebruiker beschermen zien erop toe dat eindgebruikers zeggenschap krijgen over hun eigen gegevens en vrij kunnen kiezen uit een reeks opties op de digitale markten. Zakelijke gebruikers profiteren indirect van deze bepalingen doordat eindgebruikers gemakkelijker kunnen overstappen op hun platforms en diensten.

In het midden van het spectrum zien we bepalingen die rechtstreeks bedoeld zijn om zakelijke gebruikers te beschermen en te bevoordelen, maar waarvan eindgebruikers indirect profiteren. Zo zorgt de verplichting voor poortwachters om met zakelijke gebruikers contracten te sluiten onder FRAND-voorwaarden (art. 6 lid 1 onder d en k DMA) ervoor dat ook de eindgebruikers de beste aanbiedingen krijgen. Een grotere betwistbaarheid en eerlijkheid voor zakelijke gebruikers komt indirect ook de eindgebruikers ten goede, aangezien zij toegang krijgen tot een concurrerender aanbod.

Ten slotte signaleren wij ook een gemiste kans. Het lijkt erop dat de DMA geen bescherming biedt tegen poortwachters die misbruik maken van de gedragsneigingen van eindgebruikers. De poortwachter kan hierdoor in feite oneerlijke praktijken blijven toepassen. Het onderzoek naar menselijk gedrag toont aan dat mensen worden beinvloed door hun omgevings- en cognitieve beperkingen. Poortwachters controleren de keuzeomgeving van eindgebruikers en bevinden zich dus in een gunstige positie om eindgebruikers systematisch te sturen door beïnvloedingstechnieken in te zetten zoals dark patterns. Hoewel artikel 11 DMA anti-omzeilingswaarborgen bevat, laat de DMA een kans onbenut door geen duidelijke verplichting in te voeren voor poortwachters om eindgebruikers te presenteren met onbevooroordeelde keuze.

Over het geheel genomen lijken eindgebruikers baat hebben bij zowel bepalingen die hen rechtstreeks beschermen als de bepalingen die erop gericht zijn de zakelijke gebruiker te beschermen. Toch constateren wij ook dat de DMA de kans onbenut laat eindgebruikers te beschermen tegen dark patterns. Door deze gemiste kans aan te pakken, zou de DMA onbevooroordeelde keuzes voor de eindgebruiker garanderen, hetgeen ook de zakelijke gebruiker ten goede zou kunnen komen. 